PIOTR KLIMCZAK

Wyższa Szkoła Informatyki i Zarządzania, Rzeszów

\title{
Przemiany funkcjonowania wiodących przedsiębiorstw dawnego COP-u: Huty Stalowa Wola S.A. i Wytwórni Sprzętu Komunikacyjnego „PZL-Rzeszów” S.A.
}

Procesy transformacji gospodarczej, społecznej i kulturowej, związane z wdrażaniem reguł gospodarki rynkowej, dokonujące się na obszarze Polski Południowo-Wschodniej charakteryzują się poważnym zróżnicowaniem przestrzennym, a także odmiennością w odniesieniu do innych części kraju. Generalnie związane są one z osłabianiem tempa industrialnego rozwoju i zwiększaniem się roli sektorów usługowych. Wynika to z charakteru struktur społeczno-gospodarczych wykształconych we wcześniejszych okresach. Z. Zioło (1999) przyjmuje, iż na terenie Polski Południowo-Wschodniej procesy zmian struktury bazy ekonomicznej najwcześniej, bo już w 1978 r. zaznaczyły się na terenie byłego województwa krakowskiego, w następnym 10-leciu stopniowo obejmowały kolejne województwa. W nawiazzaniu do zarysowanych przez wspomnianego Autora prawidłowości, celem niniejszego opracowania jest zwrócenie uwagi na odmienność procesów restrukturyzacyjnych zachodzących w wiodących przedsiębiorstwach Centralnego Okręgu Przemysłowego, Wytwórni Sprzętu Komunikacyjnego „PZL-Rzeszów” S.A. oraz Hucie Stalowa Wola S.A., które charakteryzują się różnymi tendencjami przemian. Pierwsze z nich pomyślnie przechodzi proces dostosowania się do nowych warunków funkcjonowania powstałych po 1989 r. i zaliczane jest do grona tzw. „liderów przemian”, czyli zakładów, które radzą sobie w nowych warunkach gospodarczych. Jest jednym z nielicznych zakładów na obszarze byłego COP-u, należących do tzw. przedsiębiorstw nowoczesnych gałęzi przemysłu, który zdołał utrzymać w okresie transformacji produkcję wyrobów wysokiej technologii. Natomiast Huta Stalowa Wola to zakład, który zaliczyć można do przedsiębiorstw odznaczających się pewną recesją. Zapewnienie sobie konkurencyjności przez to przedsiębiorstwo na rynku przebiega $\mathrm{z}$ wieloma trudnościami, a podejmowane procesy restrukturyzacyjne były niedokończone. Przebieg procesów dostosowawczych i efekty restrukturyzacji są więc jakościowo różne w analizowanych przedsiębiorstwach. Różne są też z jednej strony oddziaływania tych przedsiębiorstw na sytuację społeczno-gospodarczą ich otoczenia, a z drugiej wpływ otoczenia na kształtowanie ich procesów wewnętrznych.

Analizowane przedsiębiorstwa powstały w ramach inwestycji przemysłowych Centralnego Okręgu Przemysłowego. Prace związane z budową Wytwórni Silników Nr 2 w Rzeszowie (to przedwojenna nazwa obecnej WSK „PZL-Rzeszów”) zostały zrealizowane w nadzwyczaj krótkim czasie (tzw. copowskie tempo). Budowę rozpoczęto w połowie 1937 r., 
a już jesienią 1938 r. zakład został częściowo uruchomiony. Fabryka rzeszowska produkować miała docelowo 450 silników lotniczych rocznie. Do września 1939 r. wyprodukowano ich już 50 sztuk. Budowa zakładu wpłynęła na przebieg procesów urbanizacyjnych w Rzeszowie. W 1938 r. rozpoczęto budowę bloków mieszkalnych dla pracowników Wytwórni.

Obecna Huta Stalowa Wola należała do sztandarowych inwestycją przemysłowych COP-u. Zlokalizowana została na terenie wsi Pławno - 11 kilometrów od Niska w Puszczy Sandomierskiej jako tzw. Zakłady Południowe. Był to kombinat metalurgiczny obejmujący hutę stali szlachetnej i zakłady mechaniczne, którego celem było produkowanie sprzętu obronnego. Inwestycja ta zrealizowana została również w nadzwyczaj krótkim czasie - 27 miesięcy, kosztem około $100 \mathrm{mln}$ złotych pochodzących z funduszy państwowych. Budowę kombinatu rozpoczęto 20 marca 1937 r., a już w połowie 1938 r. oddano do użytku pierwsze hale produkcyjne. Latem 1939 r. uruchomiono hutę stali oraz zakłady mechaniczne produkujące haubice i działa przeciwlotnicze. Produkcja w 1939 r. miała wynieść 5000 ton stali i 4600 ton wyrobów walcowanych. Ogólna kubatura zabudowań fabrycznych wynosiła 904 tys. $\mathrm{m}^{3}$, drogi wewnętrzne miały długość 4,5 km, sieć kolejowa 12,5 km. Zastosowano tu najnowocześniejsze procesy technologiczne polegające np. na tym, iż po raz pierwszy w Europie użyto w niej gazu ziemnego jako paliwa w piecach martenowskich i grzewczych. Przed wybuchem wojny Zakłady Południowe zatrudniały 6500 pracowników, w tym 4000 robotników bezpośrednio przy produkcji (Wańkowicz 1939, Samecki 1998). Wybuch wojny wstrzymał rozwój zakładów i osiedli przyzakładowych.

W okresie powojennym, w warunkach gospodarki centralnie sterowanej kontynuowano rozwój obu przedsiębiorstw. Nawiązywano do przyjętej koncepcji rozwoju kraju opartego na przemyśle ciężkim, w tym przemyśle zbrojeniowym. Procesy zachodzące w obu przedsiębiorstwach były do siebie bardzo podobne i wpisywały się w proces industrialnego rozwoju kraju. Od początku lat $60 . \mathrm{XX}$ wieku przedsiębiorstwa te wolno zaczęły rozwijać eksport. Głównym odbiorcą towarów przeznaczonych na eksport był ZSRR, gdzie Huta wysyłała ponad $70 \%$ towarów przeznaczonych na eksport oraz pozostałe kraje skupione w strukturze RWPG. Wiele wyrobów z uwagi na swoją małą atrakcyjność pod względem jakości i nowoczesności z trudem znajdowało zagranicznych nabywców z tzw. krajów kapitalistycznych. Było to skutkiem przynależność do bloku krajów systemu centralnego sterowania, konieczności korzystania z radzieckich doświadczeń technicznych oraz powiązaniami z ich obszarami rynkowymi. Niemniej wraz z rozwojem eksportu zakłady zdobywały cenne doświadczenie, co pozwoliło w późniejszym czasie na rozwój technologiczny firm i unowocześnienie wyrobów.

Intensywny wzrost nakładów inwestycyjnych na procesy industrializacji w latach 70 ., największy w okresie centralnego sterowania, znalazł swoje odzwierciedlenie w znacznym rozwoju obu przedsiębiorstw i ich otoczenia lokalnego. Zwiększone środki na rozwój pozwoliły im na produkcję nowych i zmodernizowanych wyrobów cechujących się nowoczesnością konstrukcji i wysokimi walorami użytkowymi. Produkty dostosowano między innymi do wymagań odbiorców zagranicznych, także krajów ekonomicznie rozwiniętych. Przedsiębiorstwa te nawiązały w tym czasie współpracę z zachodnimi firmami, podpisały umowy kooperacyjne z tamtejszymi kontrahentami i kupowały licencje na nowe produkty. Pociągnęło to za sobą intensywny rozwój Huty Stalowa Wola. Dzięki nawiązaniu współpracy z zachodnimi potentatami z branży metalurgicznej (angielską firmą K and Steelfounders and Engineers Ltd. i Coles Cranes, zachodnioniemiecką firmą Stetter z Memmingen, amerykańską firmą Clark Equipment Co. z Buchanan oraz firmą Harvester) rozwinęła ona 
produkcję maszyn budowlanych. Podobnie WSK „PZL-Rzeszów” w 1976 r. podpisała kontrakt $\mathrm{z}$ kanadyjską firmą Pratt \& Whitney, światowym potentatem w branży lotniczej.

Działania te wpłynęły na wyraźny wzrost zatrudnienia. W 1965 r. Huta Stalowa Wola zatrudniała 13600 pracowników, a w 1975 r. wzrosło ono do 20950 osób, tj. o 54\%. Znacznie zwiększyła się liczba pracowników umysłowych, co było niezbędne przy wprowadzaniu nowych technologii czy urządzeń. W Hucie w ciągu pięciu lat (1966-1970) kadra pracowników inżynieryjno-technicznych wzrosła o ponad 1/3 (700 osób) i podobny wzrost zatrudnienia miał miejsce w Wytwórni Sprzętu Komunikacyjnego w Rzeszowie (WSK „PZL-Rzeszów”).

Analizowane przedsiębiorstwa wpływały na znaczą aktywizację ,terenów gospodarczo zapóźnionych", poprzez wykorzystanie dużych zasobów wolnej siły roboczej (Dobrowolska 1968, Winiarski 1976, Zioło 1978, 1980). Huta uruchomiła zakłady filialne w Leżajsku (1970), Zaklikowie (1971), Strzyżowie (1972), Janowie Lubelskim (1972) oraz Lubaczowie (1977). Natomiast WSK „PZL-Rzeszów” otwarła nowe zakłady w Ropczycach (1964), Przeworsku (1968), Żołyni (1975), Dynowie (1979) oraz w Bartkówce (1980). W niektórych przypadkach decyzja o wyborze miejsca lokalizacji zakładu filialnego nie miała uzasadnienia ekonomicznego a spełniała funkcje społeczne, głownie aktywizując zasoby pracy. Spodziewano się, że pozwoli to macierzystym zakładom na uporządkowanie asortymentowe produkcji i uzyskanie nowej powierzchni produkcyjnej.

Załamanie gospodarki w końcu lat 70. w istotny sposób wpłynęło na kondycję analizowanych przedsiębiorstw, co przejawiało się m.in. w drastycznym zmniejszeniu środków przeznaczanych na inwestycje produkcyjne. Władze centralne ograniczyły przydział dewiz na zakup technologii, maszyn i urządzeń, co pogorszyło związki kooperacyjne z zachodnimi partnerami. Kumulacja niekorzystnych zjawisk w latach 80., indukowanych przez chylącą się ku upadkowi gospodarkę centralnie sterowaną, mocno wpłynęła na pogorszenie sytuacji ekonomicznej w analizowanych przedsiębiorstwach.

$\mathrm{Na}$ etapie industrialnym przemysł był uznawany za podstawowy czynnik rozwoju społeczno-gospodarczego, który wyznaczał przebieg innych procesów, w tym także procesów urbanizacji. Istniała więc ścisła korelacja dodatnia między industrializacją a uprzemysłowieniem wynosząca około 0,85 (Rakowski 1980). Oba omawiane zakłady przemysłowe na zasadzie łańcucha sprzężeń przyczynowo-skutkowych wpływały na powstawanie i rozwój ośrodków miejskich - Stalowej Woli i Rzeszowa. Lokalizacja i wzrost zakładów wiązały się z powstawaniem i rozwojem niezbędnej infrastruktury oraz szeregu instytucji dla funkcjonowania przemysłu. Wokół zakładów wskutek urbanizacji obszarów wiejskich doszło do wykształcenia się osiedli mieszkaniowych, czy - jak w przypadku Stalowej Woli - całego miasta przemysłowego ${ }^{1}$. Rozpoczęte w okresie przedwojennym prace $\mathrm{z}$ tego zakresu kontynuowano po wojnie. Wraz z budową Huty Stalowa Wola wznoszono osiedla mieszkaniowe łącznie z niezbędną infrastrukturą. Budowano szkoły, hotele, stołówki, domy kultury, obiekty rekreacyjno-sportowe. W 1954 r. z chwilą otrzymania praw miejskich Huta przekazała władzom miejskim wybudowane osiedla łącznie z urządzeniami komunalnymi. W dalszym ciagu przedsiębiorstwo przeznaczało środki na finansowe na dalszy rozwój infrastruktury, m.in. budowę centrali telefonicznych, dworców autobusowych, mostów,

\footnotetext{
${ }^{1} \mathrm{~W}$ analizie tych procesów istotną rolę mają prace wykonane w szkole Prof. Marii Dobrowolskiej, która organizowała i była wieloletnim kierownikiem byłej Katedry Geografii Ekonomicznej, a później rozwijane przez Jej Uczniów.
} 
szpitali, oczyszczalni ścieków. Wraz z powstaniem w mieście w latach 70. spółdzielni mieszkaniowej Huta przekazywała także fundusze na budowę mieszkań dla swoich pracowników oraz budowano mieszkania zakładowe. W okresie gospodarki centralnie sterowanej, Huta Stalowa Wola była głównym organizatorem życia społeczno-kulturowego miasta. Podobnie WSK „PZL-Rzeszów” z uwagi na swoją lokalizację wraz z innymi zakładami przemysłowymi była organizatorem życia mieszkańców i w głównym stopniu kształtowała przestrzeń Rzeszowa. Jednak w obu przypadkach działania służące rozwijaniu usługowych działów gospodarki były niewystarczające w stosunku do tempa uprzemysłowienia, co skutkowało negatywnymi konsekwencjami w funkcjonowaniu struktury społeczno-gospodarczej. Istniała silna dysharmonia strukturalna między stopniem rozwoju procesów industrializacji i urbanizacji. Wskazują na to prace A. Fajfereka i Z. Zioło (1980, 1984, 1999), którzy określili na terenie Polski Południowo-Wschodniej stopień wyprzedzenia procesów urbanizacji przez procesy industrializacyjne. Intensywny rozwój zakładów wymagał zwiększania liczby pracowników, możliwe było to tylko poprzez zatrudnienie siły roboczej z pobliskich wsi, co przejawiało się w urbanizacji obszarów wiejskich w zakresie źródeł utrzymania. Zrodziło to zjawisko dwuzawodowości, tzw. grupa chłopo-robotników, którzy łączyli zatrudnienie w zakładzie przemysłowym z pracą we własnym gospodarstwie. Obrazują to dojazdy do pracy, tzw. migracja wahadłowa. Wśród załogi Huty i WSK Rzeszów do pracy dojeżdżało ponad $60 \%$ ogółu zatrudnionych (podczas gdy na terenie kraju ok. 45\%). W roku 1970 do pracy w Hucie dojeżdżało ponad 11 tys. osób, a zatrudnienie wynosiło 17,2 tys. osób. Pracownicy dowożeni byli z 300 różnych wsi. Z punktu widzenia krótkoterminowych korzyści codzienny dowóz pracowników był tańszą formą transferu siły roboczej od migracji stałej, stąd zarówno w HSW, jak i w WSK utworzono własną sieć transportu pracowniczego. W odniesieniu do układu lokalnego występowanie zjawiska dwuzawodowości pociągało szereg negatywnych skutków nie tylko w aspekcie ekonomicznym (jeszcze w latach 60. szacowano, że ta kategoria wytwarza w przemyśle ok. 25$28 \%$ dochodu mniej niż inne grupy pracownicze), ale także społecznym, kulturowym i psychologicznym (Kolbusz 1965, Dobrowolska 1976). Na marginesie warto zauważyć, że rozwój transportu pracowniczego hamował rozwój lokalnego systemu komunikacji, determinował też rozwój lokalnej sieci osadniczej (Sagan 1995). Jednak w wielu współczesnych teoriach rozwoju lokalnego i regionalnego istnienie dużej liczby dojeżdżających pracowników stanowi miarę mobilności siły roboczej i jest uznawane za jedną z istotnych cech wzrostu regionu (Rykiel 1997).

Dokonujące się w ostatnich trzynastu latach w Polsce procesy transformacji gospodarczej, społecznej oraz nasilenie się impulsów pochodzących z zewnątrz zrodziły potrzebę dostosowania się badanych zakładów do nowych realiów gospodarczych i w istotny sposób wpłynęły na lokalną strukturę społeczno-gospodarczą.

Oba zakłady osiągnęły największe zdolności wytwórcze w połowie lat 80., a więc w momencie, gdy zapotrzebowanie na ich wyroby zaczęło się wyraźnie zmniejszać. Jednak proces recesji gospodarczej związanej z procesami transformacji dotknął te zakłady nieco później niż $\mathrm{w}$ innych regionach. W całym regionie rzeszowskim, który opierał swoją bazę ekonomiczną na zakładach zbrojeniowych powstałych w ramach COP regres przemysłu wystąpił najpóźniej. W dawnym województwie tarnobrzeskim symptomy tego zjawiska widoczne są dopiero od 1980 r., w województwie rzeszowskim od 1985 r. 
Tabela 1. Dynamika zatrudnienia w przemyśle

w województwach leżących na obszarze byłego COP w latach 1976-1989

\begin{tabular}{|l|c|c|r|r|r|r|r|r|}
\hline \multirow{2}{*}{ Województwa } & \multicolumn{10}{|c|}{ Lata } \\
\cline { 2 - 10 } & 1976 & 1978 & 1980 & 1982 & 1984 & 1986 & 1988 & 1989 \\
\hline Kielce & 100,0 & 100,6 & 98,0 & 91,8 & 89,5 & 86,5 & 84,4 & 80,6 \\
\hline Krosno & 100.0 & 106,3 & 107,1 & 100,9 & 101,7 & 98,7 & 98,4 & 96,9 \\
\hline Przemyś1 & 100,0 & 100,9 & 99,6 & 98,3 & 100,6 & 98,9 & 98,6 & 97,4 \\
\hline Rzeszów & 100,0 & 103,3 & 109,3 & 107,4 & 109,8 & 109,7 & 109,0 & 107,2 \\
\hline Tarnobrzeg & 100,0 & 104,4 & 106,4 & 102,2 & 98,1 & 98,4 & 97,3 & 95,6 \\
\hline Tarnów & 100,0 & 101,4 & 101,6 & 91,6 & 88,5 & 85,9 & 84,1 & 83,0 \\
\hline
\end{tabular}

Źródło: Zioło 1999

Wytwórnia Sprzętu Komunikacyjnego „PZL-Rzeszów” S.A. należy do tych przedsiębiorstw, w których proces dostosowania się do nowych warunków prowadzenia działalności gospodarczej przebiega pomyślnie. Przedsiębiorstwo jest producentem silników lotniczych turboodrzutowych, turbowałowych, turbośmigłowych oraz tłokowych zarówno do zastosowań wojskowych, jak i cywilnych, przekładni śmigłowcowych, części silników lotniczych i przekładni dla klientów zewnętrznych, turbosprężarek dla przemysłu motoryzacyjnego, kolejowego, stoczniowego, tłumików drgań, odlewów, odkuwek, części maszyn i urządzeń dla przemysłu motoryzacyjnego i maszynowego. W 1991 r. z powodu załamania się eksportu do ZSRR (eksport zmniejszył się o 3/4) zakład utracił płynność finansową, w konsekwencji szybko zaczęło narastać zadłużenie przedsiębiorstwa. Rozpoczął się proces restrukturyzacji zakładu. Zredukowano zatrudnienie z 10800 do 5800 pracowników w 1992 r. Proces szybkiego „odchudzania” firmy przyczynił się do wyhamowania tempa narastania zadłużenia. Tak znaczna i w dużej mierze decydująca o późniejszym sukcesie firmy redukcja zatrudnienia była możliwa głównie dzięki położeniu zakładu na terenie dużego miasta, jakim jest Rzeszów. Część ze zwalnianych pracowników znalazła zatrudnienie w rodzącym się sektorze usług, a wielu często uruchamiało własne przedsiębiorstwa. W 1993 r. WSK-Rzeszów po przeprowadzeniu bankowego postępowania ugodowego zostało oddłużone, a w 1994 r. przekształcone je w jednoosobową spółkę Skarbu Państwa. Została utworzona komplementarna struktura pozwalająca na działanie w pełnym zakresie produkcji, od projektu, poprzez wykonawstwo półwyrobów odlewniczo-kuźniczych, obróbkę, montaż, próby i testy gotowych wyrobów aż do pełnej obsługi posprzedażnej i serwisowej.

W marcu 2002 r. WSK-Rzeszów została sprywatyzowana, zakład kupiła amerykańska firma „Pratt \& Whitney” za 70 mln dolarów i stała się właścicielem 85\% akcji WSK-Rzeszów, 15\% przejęli pracownicy. Ponadto nowy właściciel w okresie 5 najbliższych lat dokona w spółce inwestycji o wartości przekraczającej $70 \mathrm{mln}$ dolarów, zobowiązał się również do podniesienia kapitału firmy, a także transferu technologii i utworzenia nowej gamy produktów.

Od 1994 r. w rzeszowskiej wytwórni następował szybki wzrost przychodów oraz poprawa wydajności pracy. Zakład co roku osiągał realny wzrost sprzedaży, przekraczający poziom inflacji. Od 1995 r. kształtował się on na poziomie średnio 20\% rocznie. W 2000 r. przychody ze sprzedaży produktów stanowiły 96,3\% przychodu ogółem, przedsiębiorstwo funkcjonowało więc dzięki produkcji a nie sprzedaży majątku, czy środków pochodzących z budżetu państwa. W 2002 r. wskutek kumulacji niekorzystnych czynników zewnętrznych 
wyniki finansowe firmy były gorsze niż rok wcześniej (spadek wielkości sprzedaży o $77 \mathrm{mln}$ zł w porównaniu z 2001 r.), nie udało się przedsiębiorstwu zrealizować planu sprzedaży. Było to efektem recesji w przemyśle lotniczym, kontynuowania polityki „mocnej złotówki" oraz utrzymywania się dekoniunktury na europejskim i krajowym rynku motoryzacyjnym. Czynnikiem o charakterze wewnętrznym znajdującym odzwierciedlenie w spadku wielkości sprzedaży był wpływ procesu prywatyzacji WSK „PZL-Rzeszów” na kontakty handlowe.

Tabela 2. Dynamika sprzedaży w WSK „PZL-Rzeszów” w latach 1995-2002 na tle średniorocznej inflacji

\begin{tabular}{|c|c|c|c|}
\hline Lata & $\begin{array}{c}\text { Sprzedaż w cenach bieżących } \\
\text { (rok poprzedni = 100) }\end{array}$ & Inflacja średnioroczna & $\begin{array}{c}\text { Sprzedaż w cenach stałych } \\
\text { (rok poprzedni = 100) }\end{array}$ \\
\hline 1995 & - & 21,6 & - \\
1996 & 129,4 & 18,5 & 106 \\
1997 & 117,9 & 13,0 & 99 \\
1998 & 124,0 & 12,5 & 109 \\
1999 & 109,0 & 8,6 & 96 \\
2000 & 123,4 & 9,8 & 113 \\
2001 & 110,9 & 5,5 & 101 \\
2002 & 80,2 & 1,9 & 76 \\
\hline
\end{tabular}

Źródło: Opracowanie własne na podstawie danych z WSK-Rzeszów

Po redukcji zatrudnienia o 50\% na początku lat 90. w kolejnych latach następował powolny spadek zatrudnienia, ale w tym okresie znacznie rosła wydajność pracy. W 2002 r. wydajność pracy mierzona wielkością sprzedaży na jednego zatrudnionego z uwagi na niewielką sprzedaż firmy była znacznie niższa niż $2001 \mathrm{r}$.

Tabela 3. Dynamika sprzedaży na jednego zatrudnionego w WSK „PZL-Rzeszów” w latach 1995-2002

\begin{tabular}{|c|c|c|c|}
\hline Lata & $\begin{array}{c}\text { Średnioroczne } \\
\text { zatrudnienie } \\
\text { w osobach }\end{array}$ & $\begin{array}{c}\text { Sprzedaż na jednego zatrudnio- } \\
\text { nego w cenach bieżących } \\
\text { (rok poprzedni = 100) }\end{array}$ & $\begin{array}{c}\text { Sprzedaż na jednego zatrud- } \\
\text { nionego w cenach stałych } \\
\text { (rok poprzedni = 100) }\end{array}$ \\
\hline 1995 & 5887 & - & - \\
1996 & 5606 & 135,9 & 111 \\
1997 & 5351 & 123,5 & 104 \\
1998 & 5114 & 129,7 & 114 \\
1999 & 4979 & 112,0 & 99 \\
2000 & 4785 & 128,3 & 118 \\
2001 & 4547 & 116,8 & 106 \\
2002 & 4522 & 80,64 & 76 \\
\hline
\end{tabular}

Źródło: Opracowanie własne na podstawie danych z WSK-Rzeszów

Większość produkcji rzeszowskiej wytwórni kierowana jest na eksport. Głównymi odbiorcami są znane firmy w Europie Zachodniej i Ameryce (m.in. Pratt \& Whitney Canada, General Electric Aircraft Engines, Fiat Avio, Rolls Royce, United Technology). 
Tabela 4. Dynamika eksportu w WSK „PZL-Rzeszów” w latach 1995-2001

\begin{tabular}{|c|c|c|c|}
\hline Rok & Wartość eksportu w tys. zł & \% wzrostu rocznie & \% eksportu w sprzed. ogółem \\
\hline 1995 & 67.883 & - & 49,3 \\
1996 & 85.022 & 125,2 & 47,7 \\
1997 & 118.159 & 139,0 & 56,2 \\
1998 & 175.241 & 148,3 & 67,2 \\
1999 & 206.042 & 117,6 & 72,5 \\
2000 & 259.927 & 126,2 & 74,1 \\
2001 & 305.687 & 117,6 & 78,6 \\
\hline
\end{tabular}

Źródło: Opracowanie własne na podstawie danych z WSK-Rzeszów

Wśród dwunastu pierwszych firm, będących odbiorcami produktów WSK, do których trafia dwie trzecie sprzedaży, jest tylko jedna krajowa firma PZL-Świdnik.

Huta Stalowa Wola bardzo mocno odczuła skutki załamania się eksportu i ograniczenia rynku wewnętrznego. Na początku lat 90. nastąpił spadek produkcji hutniczej, co wynikało nie tylko ze zmniejszenia popytu na stalowowolskie półfabrykaty, ale również z ograniczeń w dostawie energii, zwłaszcza gazu. Spadło również zapotrzebowanie na maszyny budowlane, główny produkt przedsiębiorstwa. Rozpoczął się proces restrukturyzacji zakładu, którego przebieg jest bardzo wolny z uwagi na wielkość tego zakładu, skomplikowaną strukturę organizacyjną oraz konieczność uwzględniania we wszystkich tych procesach skutków społecznych, głównie koniecznej restrukturyzacji zatrudnienia. W latach 1991-1993 spadała sprzedaż przedsiębiorstwa i rosło zadłużenie. Od 1994 r. do 1996 r., kiedy przeprowadzono w Hucie postępowanie ugodowe z bankami w sprawie zadłużenia firmy, nastąpiła pewna poprawa sytuacji. Firma zaczęła wykazywać zyski. Jednak w struk-

turze przychodów duży był udział środków pozyskiwanych z budżetu państwa (formalne dotacje, zwolnienia z opłat na ZUS, podatki i inne ukryte formy wsparcia, środki pozyskane z Agencji Rozwoju Przemysłu, dotacje z tytułu Planu Mobilizacji Gospodarki na utrzymanie linii produkcyjnych gotowych na wypadek wojny). Od 1997 r. Huta ponownie ma ujemny wynik finansowy. Nastąpił też wyraźny spadek dynamiki sprzedaży.

Tabela 5. Dynamika sprzedaży w HSW* w latach 1995-2000 na tle średniorocznej inflacji

\begin{tabular}{|c|c|c|c|}
\hline Lata & $\begin{array}{c}\text { Sprzedaż w cenach bieżą- } \\
\text { cych (rok poprzedni = 100) }\end{array}$ & Inflacja średnioroczna & $\begin{array}{c}\text { Sprzedaż w cenach stałych } \\
\text { (rok poprzedni = 100) }\end{array}$ \\
\hline 1995 & - & 21,6 & - \\
1996 & 119,5 & 18,5 & 98 \\
1997 & 119,7 & 13,0 & 101 \\
1998 & 110,5 & 12,5 & 97 \\
1999 & 93,1 & 8,6 & 82 \\
2000 & 107,4 & 9,8 & 99 \\
2001 & 89,3 & 5,5 & 81 \\
2002 & 83,3 & 1,9 & 79 \\
\hline
\end{tabular}

* Dane dotyczą całej Grupy Kapitałowej HSW S.A 
Sytuacja zatrudnieniowa w przedsiębiorstwie jest bardzo trudna. W 1991 r., kiedy likwidowano formę kombinatu, w HSW zatrudnienie wynosiło 17086 pracowników. W ciagu dwóch następnych lat (do 1993 roku) zmniejszyło się ono o 2360 osób. Od tego czasu zatrudnienie było utrzymywane na tym samym poziomie, zmiany były bardzo niewielkie, a w ostatnich dwóch latach jego poziom spadł do około 8 tys. pracowników. O trudnej sytuacji Huty świadczy zbyt wolny proces dostosowania poziomu zatrudnienia w stosunku do produkcji.

Tabela 6. Dynamika sprzedaży na jednego zatrudnionego w HSW* w latach 1995-2002

\begin{tabular}{|c|c|c|c|}
\hline Lata & $\begin{array}{c}\text { Średnioroczne } \\
\text { zatrudnienie } \\
\text { w osobach }\end{array}$ & $\begin{array}{c}\text { Sprzedaż na jednego zatrudnione- } \\
\text { go w cenach bieżacych (rok po- } \\
\text { przedni = 100) }\end{array}$ & $\begin{array}{c}\text { Sprzedaż na jednego zatrudnio- } \\
\text { nego w cenach stałych (rok po- } \\
\text { przedni = 100) }\end{array}$ \\
\hline 1995 & $14740^{*}$ & - & - \\
1996 & 14650 & 120,2 & 99 \\
1997 & 14477 & 121,1 & 102 \\
1998 & 13926 & 114,9 & 102 \\
1999 & 14751 & 87,9 & 78 \\
2000 & 11085 & 142,9 & 131 \\
2001 & 8024 & 123,4 & 112 \\
2002 & 8088 & 82,6 & 78 \\
\hline
\end{tabular}

* Dane dotyczą całej Grupy Kapitałowej HSW S.A

\section{Źródło: Opracowanie własne na podstawie danych z HSW}

Huta Stalowa Wola należy do zakładów, które wpisane zostały do programów rządowych obejmujących restrukturyzację przedsiębiorstw przemysłu obronnego oraz restrukturyzację hutnictwa. Programy te umożliwiają ograniczenie zasobów osobowych firmy przez wprowadzenie świadczeń przedemerytalnych w wymiarze pełnej emerytury. Dotychczas zakład nie był w stanie ponosić kosztów ustawowych koniecznych zwolnień grupowych. Niekorzystna jest struktura zatrudnienia z uwagi na staż. Występuje zjawisko starzenia się załogi, spowodowane głównie brakiem nowych przyjęć do pracy.

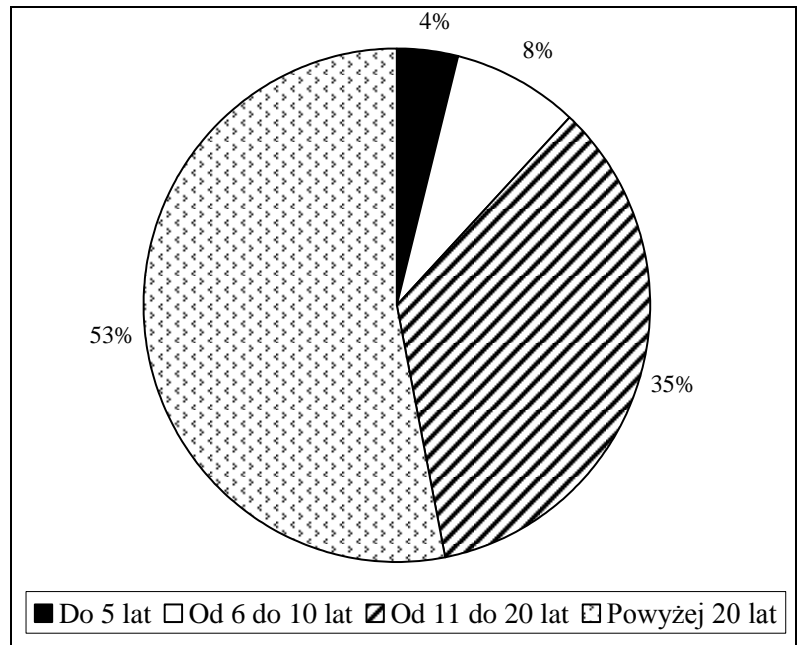


Ryc. 1. Struktura zatrudnienia w HSW wg stażu w 2001 r.

Źródło: Opracowanie własne na podstawie danych z HSW

Obecnie około 50\% sprzedaży Huty trafia na rynek krajowy, 25\% na rynek Ameryki Północnej, a niewiele ponad 12\% do krajów Unii Europejskiej. Po gwałtownym załamaniu się eksportu w 1991 r. (sprzedaż na rynki zagraniczne na poziomie $80 \mathrm{mln}$ USD) Huta powoli odzyskiwała równowagę w sprzedaży eksportowej. Ponad $20 \%$ wartości eksportu przypada na części zamienne, a wyroby hutnicze i odkuwki obejmują około 13\%. Huta jest głównie eksporterem spycharek gąsienicowych (około 60\% eksportu), jednak w ostatnich czterech latach następuje spadek zamówień na ten wyrób ze strony odbiorców zagranicznych.

$\mathrm{Z}$ początkiem lat 90 . nastąpiło całkowite załamanie produkcji dla celów obronnych. Najdłużej, bo do 1994 r. produkowano haubice, były to nieznaczne zamówienia po kilkanaście sztuk rocznie. W 1998 r. produkcja wojskowa w HSW spadła poniżej 1\% wartości sprzedaży. W ostatnich latach Huta nawiązała współpracę ze szwedzką firmą Bofors i powraca do produkcji wojskowej. Jednak rozwój tego profilu produkcji zależeć będzie od wojskowych zamówień. Istnieje też przekonanie wśród kadry zarządzającej w Hucie, że odrodzenie produkcji wojskowej spowoduje rozwój technologiczny i podniesie dyscyplinę produkcyjną w zakładzie.

Przedstawiona analiza wskazuje, iż przebieg procesów transformacyjnych w prezentowanych przedsiębiorstwach jest zupełnie odmienny. Wyjście z sytuacji kryzysowej w WSK „PZL-Rzeszów” zakończyło się pewnym sukcesem głównie dzięki temu, że w przedsiębiorstwie zdecydowano się na przeprowadzenie głębokiego procesu restrukturyzacji. W Hucie Stalowa Wola ciężar trudnej sytuacji finansowej w przedsiębiorstwie brało na siebie państwo, co przyczyniło się do powstania niekorzystnego wzorca, uzależnienia się od decyzji podejmowanych na zewnątrz i całkowitego braku wszelkiej inicjatywy wewnętrznej w celu poprawy sytuacji ekonomicznej oraz przyjęcia postawy roszczeniowej. Huta liczyła na rozwiązanie swoich problemów przez rząd, czy parlament, czekała na zamówienia MON i na kontrakty rządowe. Proces restrukturyzacji w Hucie był utrudniony z uwagi na specyficzną lokalizację, restrukturyzacja przedsiębiorstwa wymagała dostosowania zatrudnienia do wielkości produkcji, jednak zakład był największym pracodawcą na lokalnym rynku pracy, stąd próby racjonalizacji zatrudnienia kończyły się silnym sprzeciwem związków zawodowych i pracowników, którzy nie mieli żadnych perspektyw na inną pracę.

\section{Literatura}

Dobrowolska M., 1976, Przeobrażenia struktur regionalnych w Polsce oraz kierunki analizy, [w:] Studia nad Ekonomika Regionu, Katowice

Demograficzno-osadnicze procesy transformacji w Tarnobrzeskim Rejonie Uprzemystawianym, red. Dobrowolska M., 1968, Zeszyty Badań Rejonów Uprzemysławianych, KBRU PAN, z. 29, Warszawa

Dziemianowicz W., 1999, Transformacja gospodarcza nowych województw, „Polska Regionów” nr 8

Fajferek A., Zioło Z., 1983, Opóźnienie procesów urbanizacji w stosunku do procesów industrializacji w woj. tarnobrzeskim, Zeszyty Badań Rejonów Uprzemysławianych, KBRU PAN, z. 77, Warszawa, s. 127-186

Fajferek A., Zioło Z., 1979, Próba określenia stopnia wyprzedzenia procesów urbanizacji przez procesy industrializacji, Zeszyty Badań Rejonów Uprzemysławianych, KBRU PAN, nr 71, Warszawa 
Garbacz D., 1998, Spotkanie z wielkim przemystem. Huta Stalowa Wola 1938-1998, Stalowa Wola Gołębiowski J., 2000, COP. Dzieje industrializacji w rejonie bezpieczeństwa 1922-1939, Kraków

Gorzelak G., Regionalne oblicze polskiej transformacji w latach 1990-2005, [w:] Przedsiębiorczość i prywatyzacja, red. A. Mync, B. Jałowiecki, Biuletyn KPZK, z. 168

Kloc K., 2000, Szok przystosowań, „Nowe Życie Gospodarcze” nr 30

Kolbusz F., 1965, Wpływ uprzemystowienia kraju na społeczno-ekonomiczny charakter indywidualnych gospodarstw chtopskich, Warszawa

Kosieradzki W., 1939, Plan Centralnego Okregu Przemystowego, Warszawa

Kukliński A., 1997, Diagnoza stanu gospodarki przestrzennej Polski. Wstepne wyniki badań, [w:] Problematyka przestrzeni europejskiej, Warszawa

Kwiatkowski E., 1933, Dysproporcje, Kraków

Kwiatkowski E., 1939, Polityka inwestycyjna, „Polska Gospodarcza” z. 9

Kwiatkowski E., 1939, Trzyletni plan inwestycyjny, „Przegląd Gospodarczy” z. 7

Kwiatkowski E., 1935, W walce z teraźniejszościq o lepsza przyszłość gospodarczq, Warszawa

Lijewski T., 1993, Zmiany przestrzennego zagospodarowania Polski w latach 1945-1989, Warszawa

Rakowski W., 1980, Uprzemystowienie a proces urbanizacji, Warszawa

Rykiel Z., 1995, Relacje centrum peryferie w Polsce w warunkach transformacji ustrojowej, Geographia Polonica, t. 66, Warszawa

Sagan I., 1995, Procesy uprzemysłowienia w powojennej Polsce, Gdańsk

Samecki W., 1998, Centralny Okręg Przemysłowy 1936-1939, Wrocław

Szczepański J., 1973, Zmiana społeczeństwa polskiego w procesie uprzemystowienia, Warszawa

Turski R., 1965, Między miastem a wsia, Warszawa

Wańkowicz M., 1939, Sztafeta, Warszawa

Wieczorek P., 1998, Polski przemyst obronny po 1990 roku, „Wiadomości Statystyczne” nr 6

Winiarski B., 1976, Polityka regionalna, Warszawa

Zioło Z., 1999, Transformacja struktur subregionalnych Polski Poludniowo-Wschodniej w okresie zmian systemu gospodarowania, Kraków

Zioło Z., 1991, Województwo tarnobrzeskie w badaniach Instytutu Geografii Wyższej Szkoły Pedagogicznej im. Komisji Edukacji Narodowej w Krakowie, [w:] Zeszyty Badań Regionu Tarnobrzeskiego, Kraków-Tarnobrzeg, s. 105-163

Zioło Z., 1984, Wplyw polityki państwa na rozwój i przemiany struktury przestrzennej przemystu na przyktadzie Centralnego Okręu Przemystowego, Folia Geographica. Series Geographica-Oeconomica, Vol. XVII

Zioło Z., 1980, Wplyw przemystu na rozwój społeczno-ekonomiczny regionu rzeszowskiego, Warszawa

Przemiany społeczno-ekonomiczne Tarnobrzeskiego Rejonu Uprzemysławianego, 1978, red. Z. Zioło, Seria „Problemy Rejonów Uprzemysławianych”, Warszawa 